\title{
The influence of fundamental analysis and systematic risk towards stock price of banks in Indonesia
}

\author{
Purwanto ${ }^{1)}$, Erynda Bhita Safira ${ }^{2)}$ \\ ${ }^{1,2)}$ Faculty of Business, President University, Bekasi, Indonesia
}

\begin{abstract}
This research aims to identify and gives the empirical proven of significant influences in partial and simultaneously of four independent variables towards stock price. In addition, this research chooses the population in banking industry listed on LQ45 index during the period of 2011-2014. Through purposive sampling and pooling data, this research has got 96 observations from six companies in four years with quarter basis which fulfill the criteria. Based on the result, there are debt to equity ratio, earnings-per-share, and return on equity which having significant influences towards stock price. On the other hand, systematic risk has no significant influences towards the stock price. Simultaneously, those four independent variables provide $69.7 \%$ influences to dependent variable. The rest, the 30.3\%, is influenced by other factors outside this research. Moreover, earnings-per-share is chosen as the most significant factor that influences stock price.
\end{abstract}

Keywords: Debt to Equity Ratio, Earnings per Share, Return on Equity, Systematic Risk, Stock Price

\section{Introduction}

Many people do not understand and recognize the existence of capital market, mostly, it caused by the lack of knowledge about investment itself. Investment is an asset or item purchased by the investor, with expectation it will generate income or achieve greater value in the future. One of a way to invest is investing in financial market. Financial market is a place when buyers and sellers meet to trade in financial assets such as stock, bonds, commodities, currencies, and derivatives. Financial markets divided into two kinds, which are capital market and money market. Capital market consists of investment that categorized as long-term investment, which is more than one year. Since it involves long-term investment, capital market has higher risk than money market. The instruments belong to capital market are stocks and bonds. Conversely, money market is addressed for the short-term investment. Unlike capital market, it has less risk due to the short maturity. The example of money market is certificates of deposit.

In order to reach a success investment, the investor should do some analysis. There are two kinds of analysis, which are fundamental analysis and technical analysis. Fundamental analysis is performed on historical and present data, aims to making financial forecast by involving financial statements as the basic data. This fundamental analysis is represented by financial ratios. Based on figure 1, there are ten most important financial success factors to investors, they are debt to equity ratio, earnings-per-share, sales growth, return on equity, profitability growth, earnings before interest, depreciation, and amortization growth, cash and investments on hand, gross margin, return on investment and return on asset (Ernst \& Young, 2013).

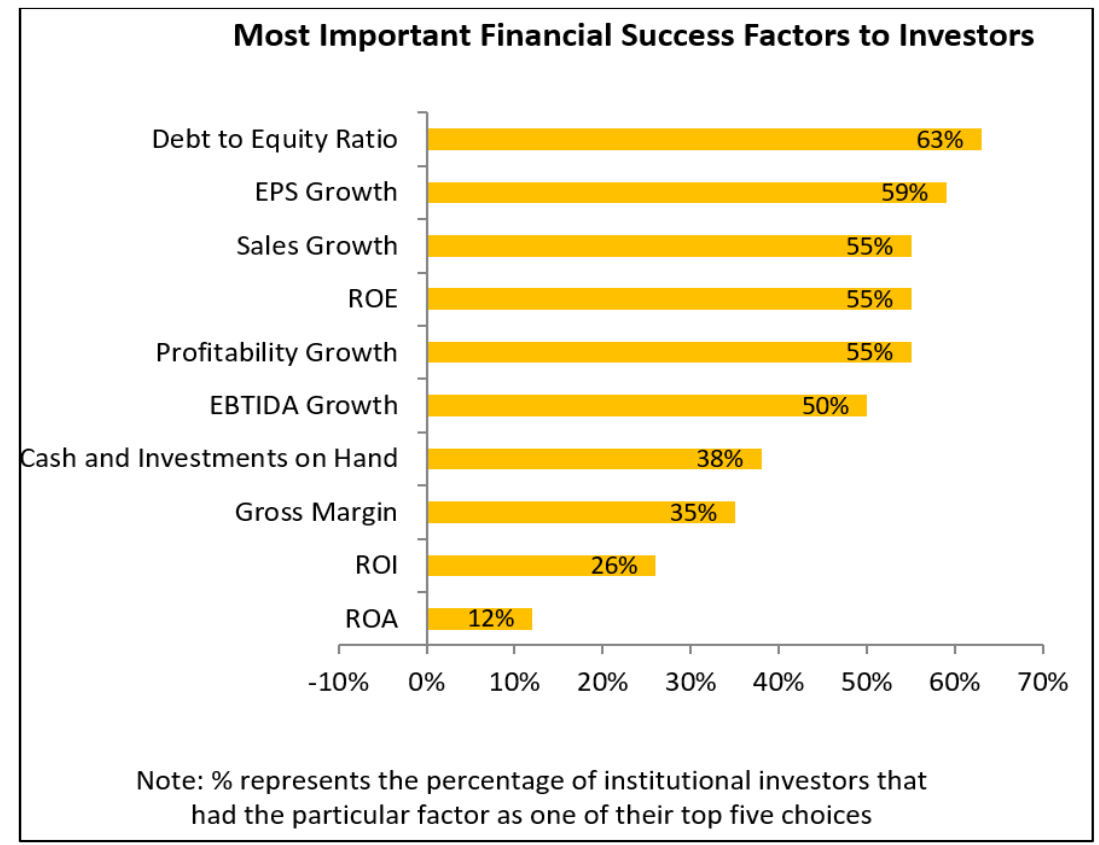

Figure 1. Financial Success Factors 
These ten ratios show the concern of the investors before deciding to invest their money in stocks. In this study, researcher is going to analyze debt to equity ratio (DER), earnings-per-share (EPS), and return on equity (ROE). Not only because those variables belong to top five according to figure 1 but also they represent a crucial function. DER, with the name itself states that DER analyzing debt, a company funded with high debt will cause a financial distress or even bankruptcy. The second ratio is earnings-per-share (EPS) that represents the ability of company to generate income for every share invested and the last is ROE that describes the amount of money that investor will get.

Besides analyzing through the fundamental analysis, there is a variable that investor should pay attention which is the rate of risk. In capital market, there are two types of risk, systematic risk and unsystematic risk. Both of them are risk that exists in a capital market, the difference is systematic risk or known as market risk or beta is cannot be eliminated and un-diversifiable, this type of risk is caused by macro factors like Bank Indonesia rate, inflation and interest rate. While unsystematic risk caused by micro factors that limited and feels by the related company only. Unlike systematic risk, unsystematic risk can be eliminated by diversification.

In stock market there is an indicator or a reflection of a group of stocks called market index. There are 11 market indices listed on Indonesia Stock Exchange, one of them is the LQ45 index. Refers to the Fact Book (2010) launched by Indonesia Stock Exchange, the LQ45 index was established to provide the market with an index that represents 45 of the most liquid stocks. It covers at least $70 \%$ of the stock market capitalization and transaction values in the regular market. The based date for the calculation of the LQ45 index is July 13, 1994, with a base value of 100. Below are some of the factors for a stock to be included in the LQ45 Index: 1) The stocks should have been listed at the IDX for at least 3 months; 2) The performance of the stock in the regular market, which include its trading value, volume and frequency of transactions; 3) The number of trading days in the regular market; 4) The stock's market capitalization at a certain time period; 5) Besidesthe liquidity and market capitalization factors, the stocks selection for The LQ45 index is also based on the financial condition and the prospect of growth of the companies.

This research was conducted to serve as a baseline for guiding investors who wants to try the stock market, but lacks the knowledge to do so. The LQ45 index has the most liquid stock in the capital market that can be a guidance for investor to know more about the movement of the stock by not only seen the trend line but also seen the fundamental analysis and systematic risk.

\section{Literature Review \\ Stock}

Constitution of Republic Indonesia no.8 of 1995 on Capital Market Chapter I Article I no.13 says that capital market is an activity concerned to the Public Offering and Trading Securities Public Company relating to Securities. One of security mentioned here is stock. According to Riyanto (2001), stock is proof of retrieval of someone in a company. Another definition says that stock is the capital raised by a company through the issue and subscription of share. All stock issued in the capital market are tradable, means the investor can buy and sell the stock. Sartono (2002) said that stock price formed through the supply demand mechanism in capital market. Stock price is volatile depends on the supply and demand of the stock itself. A stock price can be high when the stock attractive, the investors are willing to buy it and make the demand increase. Conversely, the price can be low if the stock is no longer attractive and make the investors selling their stocks. By looking at its characteristics, there are two kinds of stock, which are preferred stock and common stock. The major differences between preferred stock and common stock is preferred stock has provisions that give it some preference or priority over common stock

\section{Stock Market Indices}

Stock market index is an indicator or a reflection of a group of stocks. It measures the value section of the group of stocks by calculating its weighted average. The classification criteria may differ from one index to another. The classification may consists of the liquidity of the company. There are 11 types of stock index listed on the Indonesia Stock Exchange (IDX), which are: 1) Jakarta Composite Index (JCI) uses all listed companies as the elements for its index calculation. In order to draw the fair market value, IDX has a right to eliminate one or more companies that has small number of stocks when the market capitalization is high; 2) The LQ45 index was launched in February 1997. LQ45 index is a market capitalization-weighted index that consists of the performance of 45 most liquid companies listed on the IDX. It covers at least $70 \%$ of the stock market capitalization and transaction values in the Indonesia Stock Market; 3) Sectoral indices uses all the listed companies and categorize it based on its sector. Currently, there are 10 sectors listed, which are agriculture, mining, basic industry, various industry, consumer, property, infrastructure, finance, manufacture and trade and services; 4) Jakarta Islamic Index (JII) uses 30 stocks belong to shariah by considering the liquidity and market capitalization; 5) Kompas 100 index consists of 100 stocks of listed companies chosen by its liquidity and market capitalization with certain criteria; 6) BISNIS-27 index is the result of cooperation between IDX and Bisnis Indonesia that consists of 27 stocks of listed companies chosen by the fundamental analysis, technical analysis, transaction liquidity, accountability and management of company; 7) PEFINDO25 index is the result of cooperation between IDX and PEFINDO. This index consists of 25 stocks 
of listed companies and aims to give additional information for the investor, especially for the stocks of small medium enterprises (SME). The criteria of PEFINDO25 Index are total asset, ROE, liquidity, total outstanding share, public accounting opinion; 8) SRI-KEHATI index is the result of cooperation between IDX and Yayasan Keanekaragaman Hayati Indonesia (KEHATI). SRI stands for sustainable, responsible, and investment. This index concerns on the stocks of listed companies that have good corporate governance, encouraging sustainable business and have awareness to the environment; 9) Main Board index uses the stocks listed on the main board; 10) Development Board index uses the stocks listed on the development board; 11) Individual index consists of stock market index of each of the listed company.

\section{Market Risk}

There are two types of risk, systematic risk and unsystematic risk. Both of them are risk that exists in a capital market, the difference is systematic risk or known as market risk or beta is cannot be eliminated and un-diversifiable, this type of risk is caused by macro factors. While unsystematic risk or known as specific risk caused by micro factors that limited and feels by the related company only. Unlike systematic risk, unsystematic risk can be eliminated by diversification. Figure 2 shows both systematic and unsystematic risk in a chart.

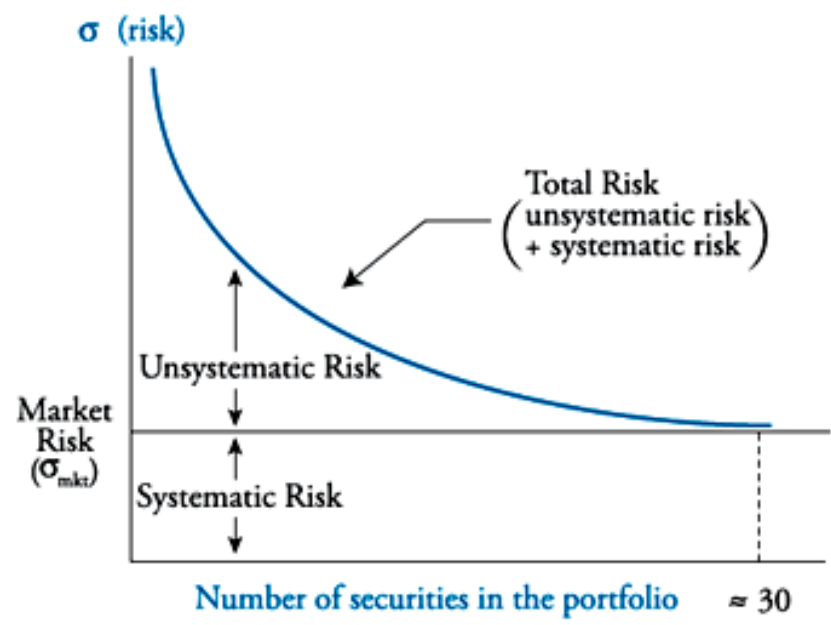

Figure 2. Systematic Risk and Unsystematic Risk

Brealey, Mayers, \& Allen (2011) says that between those variables, the one that people care about is the nondiversifiable ones, which is systematic risk or beta, because it is in line with the required return on asset increases. Systematic risk is a market risk measurement that can be calculated by dividing the covariance between the stock returns ( $\sigma \mathrm{im})$ and the market returns with the variance of the returns on the market $(\sigma \mathrm{m} 2)$. The equation can be written as follow:

$$
\beta=\frac{\sigma_{i m}}{\sigma_{m}^{2}} \ldots \ldots \ldots \ldots \ldots \ldots \ldots \ldots \ldots \ldots \ldots \ldots \ldots \ldots \ldots \ldots \ldots
$$

\section{Fundamental Analysis}

Previously explained that the price of stock will change depends on the supply and demand in the capital market caused by the level of attraction of the stock. In order to know how attractive the stock is, investor should do some analysis. There are two types of analysis, which are technical analysis and fundamental analysis. Technical analysis uses price movements and patterns on charts to predict future price movements. While fundamental analysis uses value calculated using various economic factors. Based on the table, in time horizon section, fundamental analysis uses for the long-term investment while technical analysis uses for short-term investment, in this case is trading. Fundamental analysis is performed on historical and present data, aims to making financial forecast by involving financial statements as the basic data that can be processed into financial ratio.

\section{Financial Ratios}

A financial performance of a company can be measured by analyzing its financial statements. Financial statements analysis consists of applying analytical tools and techniques to financial statements in an attempt to quantify the operating and financial conditions of a firm (Bajkowski, AAII Journal, 1999). There are three common tools used to evaluate the significance of financial statement data, which are horizontal analysis, vertical analysis, and ratio analysis. Horizontal analysis evaluates the financial statement data over a period, vertical analysis analyzes financial statement data as a percent of a base amount, and ratio analysis gives the relationship among selected items of financial statement data (Weygandt, Kimmel \& Kieso, 2010). Among those three analyzing tools, ratio analysis is able to generate the information that investors need. Divided financial ratios are 1) Liquidity ratios; ratio that measures short-term ability of the company to pay its maturing obligations and to meet unexpected needs for cash; 2) Profitability ratios; ratio that measures the 
income or operating success of a company for a given period of time; 3) Solvency ratios; ratio that measuures the ability of the company to survive over a long period of time

\section{Debt to Equity Ratio}

Debt to equity ratio is categorized as financial solvency ratio. Known as DER, this ratio compares the total liability of a company to total equity

$$
\operatorname{DER}(\%)=\frac{\text { Total Liabilities }}{\text { Total Equity }} \times 100 \%
$$

A high debt to equity ratio indicates that the company has been aggressive in financing its growth with debt, since debt include in one of source of financing. However, the earnings of the company will be volatile, because they need to pay the interest expense as the result of lending. Another function of debt to equity ratio is as a warning tool. If the number of DER is excessively high, means that the company should stop making debt. Operating a company with a lot of debt inside will lead the company to the financial distress or bankruptcy. High debt will make a high financial risk that leads to extra cautious from customers, suppliers, and investor and other parties in doing business with a firm that may not be around for long (Brealey, Mayers, \& Allen, 2011).

\section{Earnings per Share}

Earnings per share (EPS) are categorized as profitability ratio. Higher EPS will gain higher stock price, since it represents the net income generated by the number of weighted average common shares outstanding during the year. As stated EPS, which also called as net income per share, refers to the amount of common stock of the company not the preferred stock. Therefore, for the company that has a preferred stock policy, they need to deduct the preferred dividend from the net income. Here the equation of earnings per share:

$$
\text { EPS }(\$)=\frac{\text { Net Income-Preferred Dividend }}{\text { Weighted Average Common Shares Outstanding }}
$$

Comparing net business income to the equity that been invested in the business makes earnings per share has a tendency to increase over time as the business grows, especially if the investment remains the same.

\section{Return on Equity}

Return on equity or known as ROE is a financial ratio that measures the profitability from the common stockholders' point of view. It shows how many percent of net income the company earned for each dollar invested by the owners in the form of stock. There are two kinds of stocks that company might have, which are common stock and preferred stock. The major differences of common stockholders and preferred stockholders are common stockholders are the one who have a lot of portion of company's stocks and have the right in election of board of directors, while the preferred stockholders are the one who get the dividend priority from the company. This ratio, will only calculate the dollar of net income earned for each dollar invested in the common stocks.

According to regulation of Bank Indonesia, ROE is high if it is higher than $12.5 \%$ and low if ROE is lower than $5 \%$.

$$
R O E(\%)=\frac{\text { Net Income-Preferred Dividends }}{\text { Common Stock Equity }} \times 100 \%
$$

\section{Theoretical Framework}

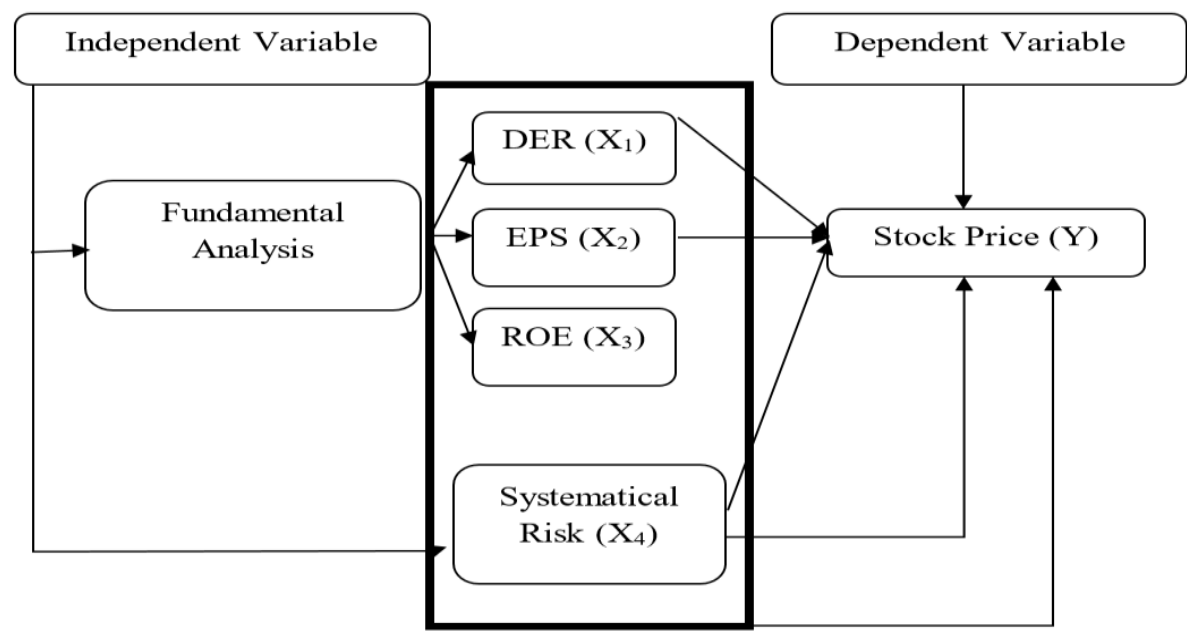

Figure 3. Theoretical Framework 
This research is going to analyze the influence of fundamental factors and Systematic risk towards stock price. Figure 3 shows that there are two types of variables involve in this research, which are independent variables and dependent variable. Independent variables consists of fundamental analysis which is represented fundamental factors to three ratios, which are DER, EPS, ROE and systematic risk. While dependent variable has one variable, which is stock price. The thick line on the figure explains the partial influence of the independent variables toward the dependent variable. While, the bold line on the figure above explains the influence of all independent variables toward the dependent variable simultaneously.

\section{Hypotheses}

"An hypotheses $(\mathrm{H})$ can be defined as a testable prediction about what you expect to happen in your study" (Ajith \& Shalini, 2001). Given the theoretical background as discussed above, this study attempts to hypothesize $(\mathrm{H})$ the following:

Hypothesis 1 : There is significance influence of debt to equity ratio towards stock price of banks listed on the LQ45 index.

Hypothesis 2 : There is significance influence of earnings-per-share towards stock price of banks listed on the LQ45 index.

Hypothesis 3 : There is significance influence of return on equity towards stock price of banks listed on the LQ45 index.

Hypothesis 4 : There is significance influence of systematic risk towards stock price of banks listed on the LQ45 index.

Hypothesis 5 : There is significance influence of DER, EPS Growth, ROE, and systematic risk towards stock price of banks listed on the LQ45 index.

\section{Research Method \\ Research Design}

In doing a research, there are two types of analyzing methods, which are quantitative analysis and qualitative analysis. Quantitative research is systematic scientific investigation of data and its variable. It shows the cause and effect relationship of independent and dependent variable, the measurement should be objective, quantitative, and statistically valid. Aliaga \& Gunderson (2000) said that quantitative research is explaining phenomena by collecting numerical data that are analyzed using mathematically based methods (in particular statistics). The specificity of quantitative research is collecting numerical data. Conversely, a qualitative research method is subjective, because it uses different methods of collecting information like interview, questionnaire, and focus group discussion. Qualitative research methods have a tendency to explain and describe meanings, concepts, definitions, characteristics, metaphors, and symbols through observation. Based on the explanations about quantitative and qualitative data, researcher uses quantitative method to analyze the factors that influence the stock price.

This research consists of one dependent variable, which is stock price, and four independent variables, which are DER, EPS, ROE, and Beta. The information gathered during period of 2011-2014, which is four years, with quarterly basis. These secondary data are managed by using panel data method. Panel data, also known as longitudinal data or cross-sectional time series data, are where the data were observed at more than two periods (Stock \& Watson, Introduction to Econometrics, 2003). A panel data should have $n$ cases over $t$ periods. Therefore, the total data $(\mathrm{N})$ is $n$ multiple by $t$.

\section{Population and Sample}

Research population is total objects or individuals who the characteristics are going to be predicted (Sugiyono, 2008). The population of this study is all banks that registered on the LQ45 index. Based on data, six banks are actively traded on the LQ45 index.

Table 1. List of Banks Listed in LQ45

\begin{tabular}{cll}
\hline No. & \multicolumn{1}{c}{ Bank } & Ticker \\
\hline 1 & Bank Central Asia Tbk & BBCA \\
\hline 2 & Bank Negara Indonesia Tbk & BBNI \\
\hline 3 & Bank Rakyat Indonesia (Persero) Tbk & BBRI \\
\hline 4 & Bank Tabungan Negara (Persero) Tbk & BBTN \\
\hline 5 & Bank Danamon Indonesia Tbk & BDMN \\
\hline 6 & Bank Mandiri (Persero) Tbk & BMRI \\
\hline
\end{tabular}


By combining the data from table 1 and purposive sampling technique, researcher found that 6 out of 6 banks are eligible for this study. The sample was taken by using panel data. Gujarati (2003) said that there are three types of data in measuring variable $\mathrm{Xn}$ to $\mathrm{Y}$, which are time series, cross sectional and panel data. In this study, the researcher uses panel data. Panel data, also known as longitudinal data or cross-sectional time series data, are where the data were observed at more than two periods (Stock \& Watson, Introduction to Econometrics, 2003). A panel data should have $n$ cases over t periods. Therefore, the total data $(\mathrm{N})$ is $n \times t$. In this study, the $\mathrm{n}$ is defined by six banks, while the $\mathrm{t}$ is 16 , because the researcher uses quarter basis for four years (2011-2014). Therefore, the sample size of this research is 96.

\section{Multiple Linear Regression}

Multiple-linear-regression is a statistical technique to figure out the linear correlations between independent variables and dependent variable. The dependent variable in this study is stock price, while the independent variables are debt to equity ratio, earnings-per-share, return on equity, and systematic risk. The relationship model between dependent and independent variables can be written in linear regression equation as follows:

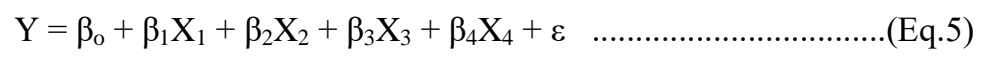

$\mathrm{Y}$ is stock price, $\beta \mathrm{o}$ is constant, $\mathrm{X} 1$ is debt to equity ratio, $\mathrm{X} 2$ is earnings per share, $\mathrm{X} 3$ is return on equity, X4 is beta, $\beta 1 \ldots . . \beta 4$ are regression coefficient and $\varepsilon$ is error. The regression coefficient value in this study plays a very important role as a basic of analysis. If $\beta$ coefficient value is positive $(+)$, it can be concluded that there is a direct effect between independent variable and the dependent variable. An increament of independent variable score will give a result in raising the value of dependent variable. Vice versa, when $\beta$ coefficient value is negative (-), it shows the negative effect where the increament of independent variable will result to decrease the dependent variable value.

\section{Result and Discusssion \\ Descriptive Statistic}

Below is the descriptive data used in this study consists of one dependent variable and four independent variables with samples $(\mathrm{N})$ of 96 for each variable. The samples are taken from 4 years on quarterly basis

Table 2. Descriptive Statistics

\begin{tabular}{lrrrrr}
\hline & N & Minimum & Maximum & \multicolumn{1}{c}{ Mean } & \multicolumn{1}{c}{ Std. Deviation } \\
\hline StockPrice & 96 & 870.00 & 13075.00 & 5840.7812 & 2892.41588 \\
DER & 96 & 4.17 & 11.35 & 7.3482 & 1.80693 \\
EPS & 96 & 105.06 & 985.01 & 463.6110 & 221.55114 \\
ROE & 96 & .10 & .39 & .2166 & .06907 \\
Beta & 96 & -7.12 & 7.61 & 1.0032 & 1.92816 \\
Valid N (listwise) & 96 & & & & \\
\hline
\end{tabular}

According to the table 2, the information of both variables are elaborated as follows: 1) Stock price is categorized as dependent variable. It has a mean value of 5840.7812 with standard deviation of 2892.41588. The minimum value of stock price is 870.00, occurs on Bank Tabungan Negara in the fourth quarter of 2014, and the maximum value is 13075.00 occurs on Bank Central Asia in the first quarter of 2014; 2) Debt to Equity Ratio is categorized as independent variable. It has a mean value of 7.3482 with standard deviation of 1.80693. The minimum value of DER is 4.17 , occurs on Bank Danamon Indonesia in the third quarter of 2013, and the maximum value is 11.35 occurs on Bank Tabungan Negara in the second quarter of 2012; 3) Earnings per Share are categorized as independent variable. It has a mean value of 463.6110 with standard deviation of 221.55114. The minimum value of EPS is 105.06, occurs on Bank Tabungan Negara in fourth quarter of 2011, and the maximum value is 985.01 occurs on Bank Rakyat Indonesia in the first quarter of 2014 ; 4) Return on Equity is categorized as independent variable. It has a mean value of 0.2166 with standard deviation of 0.06907 . The minimum value of ROE is 0.10 , occurs on Bank Danamon Indonesia in the first quarter of 2014, and the maximum value is 0.39 occurs on Bank Rakyat Indonesia in the first quarter of 2011 ; 5) Systematic risk or Beta is categorized as independent variable. It has a mean value of 1.0032 with standard deviation of 1.92816. The minimum value of Beta is -7.12, occurs on Bank Danamon Indonesia in the first quarter of 2014, and the maximum value is 7.61 occurs on Bank Tabungan Negara in the first quarter of 2011. 


\section{Multiple Linear Regression}

Multiple-linear-regression is a statistical technique to figure out the linear correlations between independent variables and dependent variable. The multiple linear regression equation can be formulated from the beta in un-standardized coefficients. The standardize coefficient express all coefficients in terms of the same units and it is good to compare the size of the influences of different independent variables.

Table 3. Multiple Linear Regression Analysis

Coefficients $^{\mathrm{a}}$

\begin{tabular}{|c|c|c|c|c|c|c|}
\hline \multirow{2}{*}{\multicolumn{2}{|c|}{ Model }} & \multicolumn{2}{|c|}{ Unstandardized Coefficients } & \multirow{2}{*}{$\begin{array}{c}\text { Standardized } \\
\text { Coefficients }\end{array}$} & \multirow[t]{2}{*}{$\mathrm{t}$} & \multirow[t]{2}{*}{ Sig. } \\
\hline & & $\mathrm{B}$ & Std. Error & & & \\
\hline \multirow{5}{*}{1} & (Constant) & 2641.980 & 978.980 & & 2.699 & .008 \\
\hline & DER & -321.402 & 117.483 & -.201 & -2.736 & .007 \\
\hline & EPS & 8.022 & 1.266 & .614 & 6.338 & .000 \\
\hline & ROE & 8733.293 & 3783.692 & .209 & 2.308 & .023 \\
\hline & Beta & -50.086 & 91.087 & -.033 & -.550 & .584 \\
\hline
\end{tabular}

a. Dependent Variable: StockPrice

Based on table 3 the equation can be written as follows:

Stock Price $=2641.980-321.402 \mathrm{DER}+8.022 \mathrm{EPS}+8733.293 \mathrm{ROE}-50.086$ Beta $\ldots . .($ Eq.6)

Equation 6 above can be described as follows: 1) Constanta with the amount of 2641.980, it shows that when the independent variables which are debt to equity ratio, earnings per share, return on equity, and systematic risk are having the value of zero (0) the value of stock price become 2641.980 ; 2) Regression coefficient of debt to equity ratio $=-321.402$, multiple-regression model shows that debt to equity ratio has influence the stock price by -321.402 . It means that if the value of debt to equity ratio increase 1 point and the other variables are constant, the stock price will decrease -321.402;3) Regression coefficient of earningsper-share $=8.022$, the coefficient of earnings-per-share is 8.022. It explains that every increase of 1 point in the earnings-per-share will make the stock price increase by 8.022, by using assumption that the other variables remain constant; 4) Regression coefficient of return on equity $=8733.293$, it defines that return on equity has influence towards the stock price by 8733.293. In other word, if the other variables are constant and there is an increase of 1 point on return on equity, it makes the stock price increase by $8733.293 ; 5$ ) Regression coefficient of systematic risk $=-50.086$, it shows that the systematic risk has influence of -50.086 towards the stock price. The result explains that every increase of 1 point in the systematic risk will make the

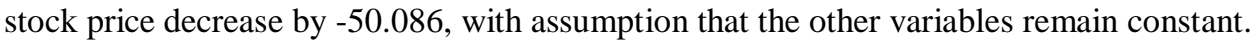

\section{Interpretation of Results}

\section{The Influence of Debt to Equity Ratio towards Stock Price}

The first hypothesis states that there is significance influence of debt to equity ratio towards stock price of banks listed on the LQ45 index. According to the table 3, this hypothesis is accepted. Debt to equity ratio has a negative influence towards the stock price, means that an increase in DER leads to a decrease in stock price. The results is supported by the theory that said the increase of debt would lead to the bankruptcy and make the stockholders are no longer interested with the stocks. It also creates a decrease in the stock price. Further reason explains that high debt will make a high financial risk that leads to extra cautious from customers, suppliers, and investor and other parties in doing business with a firm that may not be around for long (Brealey, Mayers, \& Allen, 2011). The negative significance influence of DER towards the stock price also explained by Stella (2009) that the increase of DER would make the stock become not attractive anymore because it indicates that the company is having a big portion of debt, which results in company having more liability.

\section{The Influence of Earnings per Share towards Stock Price}

The second hypothesis states that there is significance influence of earnings-per-share towards stock price of banks listed on the LQ45 index. This hypothesis is accepted. It explains that an increase in EPS will make an increase in stock price. The influence of EPS shows a positive influence, this can be happened by taking a consideration of the function of the EPS itself. Theory said that Earnings-per-Share represents the income that the company able to generate for every weighted average common stock outstanding. Therefore, higher EPS will attract more investor to buy the stock and increase the stock price. Setianingrum (2009) on her paper said that there is a positive significance influence of EPS towards the stock price, that the EPS has level 
of significance below 0.05 . In addition, she also stated that the EPS has positive influence towards the stock price.

\section{The Influence of Return on Equity towards Stock Price}

The third hypothesis states that there is significance influence of return on equity towards stock price of banks listed on the LQ45 index. This hypothesis is accepted. It explains that an increase in ROE will make an increase in stock price. ROE represents the amount of percentage of return generated for each dollar invested. ROE is the measurement of available income for each investor (Syamsuddin, 2007). Therefore, high return on equity will attract the investor and increase its stock price. Rahmi, Arfan, \& Jalaluddin (2013) in their research found that the level of significance of ROE is lower than 0.05 , means that the ROE has significant influence towards the stock price. Furthermore, it has a positive coefficient.

\section{The Influence of Systematic Risk (Beta) towards Stock Price}

The fourth hypothesis states that there is significance influence of systematic risk towards stock price of banks listed on the LQ45 index. This hypothesis is rejected. According to the T-test table, systematic risk has no significant influence towards stock price. Means that compares to other independent variables, systematic risk has small influence. In addition, it has negative influence on it. The negative influence explains that the increase of systematic risk will make the stock become unattractive and makes lower stock price. However, some investors are persist to buy a stock with high systematic risk, this caused by the characteristic of the investor itself. According to Weygandt, Kimmel, \& Kieso (2010) there are three characteristic of investor, which are conservative (low risk), balanced (medium risk), and dynamic (high risk). A high risk or dynamic investors are prepared to exposed their portfolio for having a greater risk and accept higher volatility in order to maximize the profit, they came up with a well-prepared strategy. Anastasia, Gunawan, \& Wijayanti (2003) and Setianingrum (2009) support this research. They found that the level of significance of the systematic risk is more than 0.05 , thus, systematic risk has no significant influence towards stock price.

\section{The Simultaneous Influence of Debt to Equity Ratio, Earnings per Share, Return on Equity, Beta towards Stock Price}

The hypothesis states that there is significance influence of debt to equity ratio, earnings per share, return on equity, and systematic risk towards stock price of banks listed on the LQ45 index. This hypothesis is accepted. All independent variables are simultaneously influence the dependent variable. Debt to equity ratio, return on equity, earnings per share and systematic risk are able to influence the stock price by $69.7 \%$, while the rest $30.3 \%$ is influenced by other variables that are not examined in this study. The research of Rahmi, Arfan, \& Jalaluddin (2013), Setianingrum (2009), Stella (2009), Anastasia, Gunawan, \& Wijayanti (2003), and WBBA \& Pratomo (2013) support this statement.

\section{The Most Significant Influence Factors towards Stock Price}

In order to know which factors give the most significant influence towards the stock price, the researcher sorted the level of significance of each variable from table 4.6 and find out that earnings-per-share is the most significant influence factors towards stock price of banks listed on the LQ45 during period of 2011-2014. Earnings-per-share is the ability of the company in order to generate earning for every weighted common stock outstanding. Higher EPS makes the investor trust and attractive in order to buy the stock, therefore, it makes higher stock price. Therefore, investors should pay more attention to the earnings-per-share because it has most significant influence among the other variables.

\section{Conclusion}

1. Performance of debt to equity ratio has a negative significant influence towards the stock price. The company that financed by debt will make the stock becomes too risky and not attractive. In other word, high debt to equity ratio leads to low stock price.

2. Performance of earnings-per-share has a positive significant influence towards the stock price. The more income generated by the company, the higher the earning-per-share. Higher earnings-per-share will make the stock become more attractive and make a positive movement.

3. Performance of return on equity has a positive significant influence. It indicates that high return on equity will make high stock price. This increase is caused by the function of ROE itself is to show the amount of money that investors will get from the investment.

4. Performance of systematic risk or beta has no significant influence towards the stock price. In addition, it gives negative influence to the stock price. Investor can avoid stock that has high systematic risk, in order to get a safe and secure investment.

5. Simultaneously, debt to equity ratio, earnings-per-share, return on equity, and systematic risk are simultaneously having significant influence towards the stock price by $69.7 \%$. The remaining $30.3 \%$ influence factor is caused by the other factors outside the regression. 
6. Among all the independent variables that researcher used in this study, the most significant factors that influence the stock price is earnings-per-share. It indicates that investor should pay more attention to the earnings-per-share of a bank. If the EPS gives the

\section{References}

Aliaga, M., \& Gunderson, B. (2000). Interactive Statistics (Vol. Second Edition). Prentice Hall.

Anastasia, N., Gunawan, Y. W., \& Wijayanti, I. (2003). Analisis Faktor Fundamental dan Risiko Sistematik Terhadap Harga Saham Properti di BEJ. Jurnal Akuntansi \& Keuangan , 5, 123-132.

Brealey, R. A., Mayers, S. C., \& Allen, F. (2011). Principles of Corporate Finance: Global Edition (10th edition ed.). New York, USA: McGraw-Hill.

Brigham, E. F. (2001). Manajemen Keuangan. Jakarta: Erlangga.

Brau, J. C., \& Fawcett, S. E. (2006, Summer). Evidence on What CFOs Think about the IPO Process: Practice, Theory and Managerial Implications. Journal of Applied Corporate Finance , 107-117.

Brealey, R. A., Mayers, S. C., \& Allen, F. (2011). Principles of Corporate Finance: Global Edition (10th edition ed.). New York, USA: McGraw-Hill.

Bajkowski, J. (1999, August). AAII Journal. Retrieved September 11, 2014, from AAII: http://www.aaii.com/journal/article/financial-ratio-analysis-putting-the-numbers-to-work

Ernst \& Young. (2013). Retrieved September 10, 2014, from www.ey.com

Investopedia. (2014). Dictionary: Investopedia. Retrieved September 23, 2014, from Investopedia: www.businessdictionary.com

Rahmi, A., Arfan, M., \& Jalaluddin. (2013). Pengaruh Faktor-Faktor Fundamental dan Risiko Sistematik terhdap Harga Saham (Studi pada Perusahaan Manufaktur yang terdaftar di Bursa Efek Indonesia Periode 2007-2009). Jurnal Akuntanasi Pascasarjana Universitas Syiah Kuala , 2 (2), 1-15.

Stock, J. H., \& Watson, M. W. (2003). Introduction to Econometrics. Pearson.

Sugiyono. (2008). Metode Penelitian Bisnis. Bandung: Alfabeta.

Setianingrum, R. (2009). Pengaruh Faktor-Faktor Fundamental dan Risiko Sistematik terhadap Harga Saham: Studi Kasus pada Perusahaan Manufaktur yang Listed di BEI. Surakarta: Universitas Sebelas Maret Surakarta.

Stella. (2009). Pengaruh Price to Earnings Ratio, Debt to Equity Ratio, Return on Asset, dan Price to Book Value terhadap Harga Saham. Jurnal Bisnis dan Akuntansi , 11, 97-106.

Tongco, M. D. (2007). Purposive Sampling as a Tool for Informant Selection. A Journal of Plants, People and Applied Research, 147-158.

Weygandt, J. J., Kimmel, P. D., \& Kieso, D. E. (2010). Accounting Principles: Ninth Edition. Asia: John Wiley \& Sons.

WBBA, A., \& Pratomo, W. A. (2013). Analisis Fundamental dan Risiko Sistematik terhadap Harga Saham Perbankan yang Terdaftar pada Indeks LQ45. Junal Ekonomi dan Keuangan , 1, 205-219.

Zikmun, W. G., Babin, B. J., Carr, J., \& Griffin, M. (2013). Business Research Methods. USA: Cengage Learning. 